\title{
The rainy season increases the abundance and richness of the aquatic insect community in a Neotropical reservoir
}

\author{
Santana, HS. ${ }^{a *}$, Silva, LCF. ${ }^{b}$, Pereira, CL. ${ }^{c}$, Simião-Ferreira, $J .^{c}$ and Angelini, . $^{d}$ \\ aPrograma de Pós-graduação em Ecologia de Ambientes Aquáticos Continentais, Universidade Estadual de \\ Maringá - UEM, Av. Colombo, 5790, CEP 87020-900, Jd. Universitário, Maringá, PR, Brazil

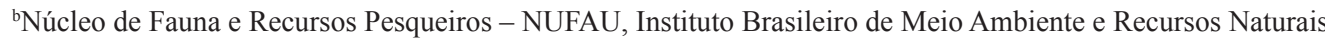 \\ Renováveis em Goiás - IBAMA/GO, Rua 229, número 95, Setor Universitário, CEP 74605-090, Goiânia, GO, Brazil \\ 'Unidade de Ciências Exatas e Tecnológicas - UnUCET, Laboratório de Pesquisas Ecológicas e Educação Científica, \\ Universidade Estadual de Goiás - UEG, BR 153, Km 98, Arco Verde, CEP 75000-000, Anápolis, GO, Brazil \\ dDepartamento de Engenharia Civil, Universidade Federal do Rio Grande do Norte - UFRN, CP 1524, \\ Campus Universitário Lagoa Nova, CEP 59078-900, Natal, RN, Brazil \\ *e-mail: herick.bio@gmail.com
}

Received: June 4, 2013 - Accepted: September 25, 2013 - Distributed: March 31, 2015

(With 4 figures)

\begin{abstract}
Alterations in aquatic systems and changes in water levels, whether due to rains or dam-mediated control can cause changes in community structure, forcing the community to readjust to the new environment. This study tested the hypothesis that there is an increase in the richness and abundance of aquatic insects during the rainy season in the Serra da Mesa Reservoir, with the premise that increasing the reservoir level provides greater external material input and habitat diversity, and, therefore, conditions that promote colonization by more species. We used the paired t test to test the differences in richness, beta diversity, and abundance, and a Non-metric Multidimensional Scaling (NMDS) was performed to identify patterns in the community under study. Additionally, Pearson correlations were analyzed between the richness, abundance, and beta diversity and the level of the reservoir. We collected 35,028 aquatic insect larvae (9,513 in dry period and 25,515 in the rainy season), predominantly of the Chironomidae family, followed by orders Ephemeroptera, Trichoptera, and Odonata. Among the 33 families collected, only 12 occurred in the dry season, while all occurred in the rainy season. These families are common in lentic environments, and the dominance of Chironomidae was associated with its fast colonization, their behavior of living at high densities and the great tolerance to low levels of oxygen in the environment. The hypothesis was confirmed, as the richness, beta diversity, and abundance were positively affected by the increase in water levels due to the rainy season, which most likely led to greater external material input, greater heterogeneity of habitat, and better conditions for colonization by several families.
\end{abstract}

Keywords: temporal variation, Serra da Mesa reservoir, zoobenthic, and level water.

\section{Período chuvoso aumenta a abundância e riqueza da comunidade de insetos aquáticos em um reservatório neotropical}

\begin{abstract}
Resumo
Alterações nos sistemas aquáticos, bem como variações nos níveis da água, sejam devido a chuvas ou pelo controle exercido pela barragem podem provocar mudanças na estruturação das comunidades fazendo com que as mesmas sejam obrigadas a se readequar às novas características do ambiente. Este estudo testou a hipótese de que ocorre aumento na riqueza e abundância de insetos aquáticos na estação chuvosa no reservatório de Serra da Mesa com a premissa que o aumento do nível do reservatório proporciona maior entrada de material alóctone, maior diversidade de habitats e, consequentemente, condições para a colonização de mais espécies. Para testar as diferenças na riqueza, diversidade beta e abundância foi utilizado o test t pareado e, além disso, foi feita uma NMDS para identificar padrões na comunidade em estudo. Foram coletados 35.028 larvas de insetos aquáticos (9513 no período seco e 25.515 no período de cheia) com predominância da família Chironomidae seguida das famílias Ephemeroptera, Trichoptera e Odonata. Dentre as 33 famílias coletadas, apenas 12 ocorreram no período de seca, enquanto todas ocorreram no período chuvoso. Essas famílias são bastante encontradas em ambientes lênticos e a dominância de Chironomidae está associada ao seu rápido processo de colonização, ao seu comportamento de viver em altas densidades e sua grande tolerância a baixos teores de oxigênio no ambiente. A hipótese testada foi corroborada visto que a riqueza, a diversidade beta e a abundância de
\end{abstract}


insetos aquáticos foram influenciadas positivamente pelo aumento do nível da água, decorrente do período chuvoso, que, provavelmente, propiciou uma maior entrada de material alóctone, maior heterogeneidade de habitat e melhores condições para a colonização das diversas famílias.

Palavras-chave: variação temporal, reservatório Serra da Mesa, zoobentos, nível da água.

\section{Introduction}

Aquatic communities are highly impacted due to the damming of the rivers for power generation (Barletta et al., 2010), causing the homogenization of environments, introduction and permanence of exotic species, extinction of local species, loss of habitat, and interruption of fish migration (Agostinho et al., 1999, 2008). Furthermore, the water level variations caused by reservoir operations (Pamplin and Rocha, 2007) alter the richness and density of many organisms and interfere with such parameters as the water transparency and input of organic matter (Hunt and Jones, 1972; Palomaki, 1994; Furey et al., 2006).

Among the various components of aquatic biota, aquatic insects have been frequently utilized for predictions with regard to impact assessment because such species respond quickly to environmental alterations through species richness and abundance modifications (Hsu and Yang, 2005; Almeida et al., 2006). In tropical reservoirs, the assemblage of aquatic insects is mainly composed of nymphs of mayflies, dragonflies, Coleoptera, Hemiptera, and Diptera, with the latter represented primarily by the family Chironomidae (Peiró and Alves, 2006; Silva et al., 2009).

In temperate environments, the main factor responsible for structuring the assemblages of aquatic insects is the temperature (Ward and Stanford, 1982). Conversely, in the tropics, where this variable does not have large variations, other variables are crucial, including physical-chemical parameters of the water, seasonality, and habitat heterogeneity (Bispo and Oliveira, 1998; Silveira et al., 2006).

There are two distinct seasons in Central Brazil, a dry season and a rainy season, and there is a clear pattern of change in the aquatic insect community in stream environments, whereby the diversity and abundance increase during drought and decrease during the rainy season (Bispo et al., 2001; Thomazi et al., 2008). The reason for this fluctuation is that the environments are more stable in the dry season, allowing species colonization and establishment; in the rainy season, however, only species with morphological adaptations that allow them to resist the force of the water and the constant disturbances caused by rain can survive (Bispo and Oliveira, 1998; Bispo et al., 2001). This pattern was observed in a tropical lake (Lucca et al., 2010) dominated by Chironomidae and Oligochaeta in both seasons but with a higher density in the dry season. Although it is known that the damming of a river can strongly alter the structure of the zoobenthic community (Jorcin and Nogueira, 2008), the temporal pattern of this particular community is still not well understood.

Accordingly, we tested the hypothesis that there is an increase in the richness and abundance of aquatic insects in the rainy season in a Neotropical reservoir, with the premise that high levels of water provide greater allochthonous material input and diversity of habitats and, thus, better conditions for colonization. Moreover, due to a lack of knowledge regarding the fauna of the study region, we also characterized the assemblage of aquatic insects in the Serra da Mesa Reservoir.

\section{Material and Methods}

\subsection{Study site}

The Serra da Mesa Reservoir is located in the north of Goiás State, near the border with the state of Tocantins (Figure 1), and is the main drainage basin of the Tocantins River and four tributaries: the Tocantinzinho, Bagagem, Almas, and Maranhão rivers (Andrade, 2002).

The dam's hydroelectric Serra da Mesa was closed in 1996 in the upper Tocantins River and became the largest reservoir in the country by volume of water and the fifth in the flooded area (Albrecht et al., 2009). The reservoir is characterized as having a tropical climate, with rainy and dry periods (Köppen AW) and average temperatures of approximately $20^{\circ} \mathrm{C}$. Moreover, the site is included in the Cerrado biome, which has two well-defined seasons: dry in winter and wet in summer, with most of the rainfall occurring from November to March (De Filippo et al., 1999).

\subsection{Sampling procedures}

Samples were collected in August and November of 2009 and March and September of 2010, with one sampling each month: two in the dry season (August 2009 and September 2010) and two in the rainy season (November 2009 and March 2010), with seven points for each sample (Figure 1).

Aquatic insects were collected using a Petersen grab device (Davanso and Henry, 2006) at deep sites to obtain three samples at each site; a hand net (mesh $250 \mu \mathrm{m}$ ) was used at shallow sites (Edia et al., 2010), with a sampling effort of five minutes per collection point. The two methodologies were used because they are complementary and faithfully represent the aquatic insect community.

The specimens were identified to the family level according to Merritt and Cummins (1996) and Mugnai et al. (2010). The biological material was preserved in $90 \%$ ethanol for later identification and thereafter preserved in $70 \%$ ethanol and deposited in the scientific collection of the Laboratory of Ecological Research and Science Education, State University of Goiás (Anápolis - Brazil).

\subsection{Data analysis}

To verify the existence of patterns in the aquatic insect community, an analysis of Non-metric Multidimensional Scaling (NMDS) was performed using the logarithm of the 


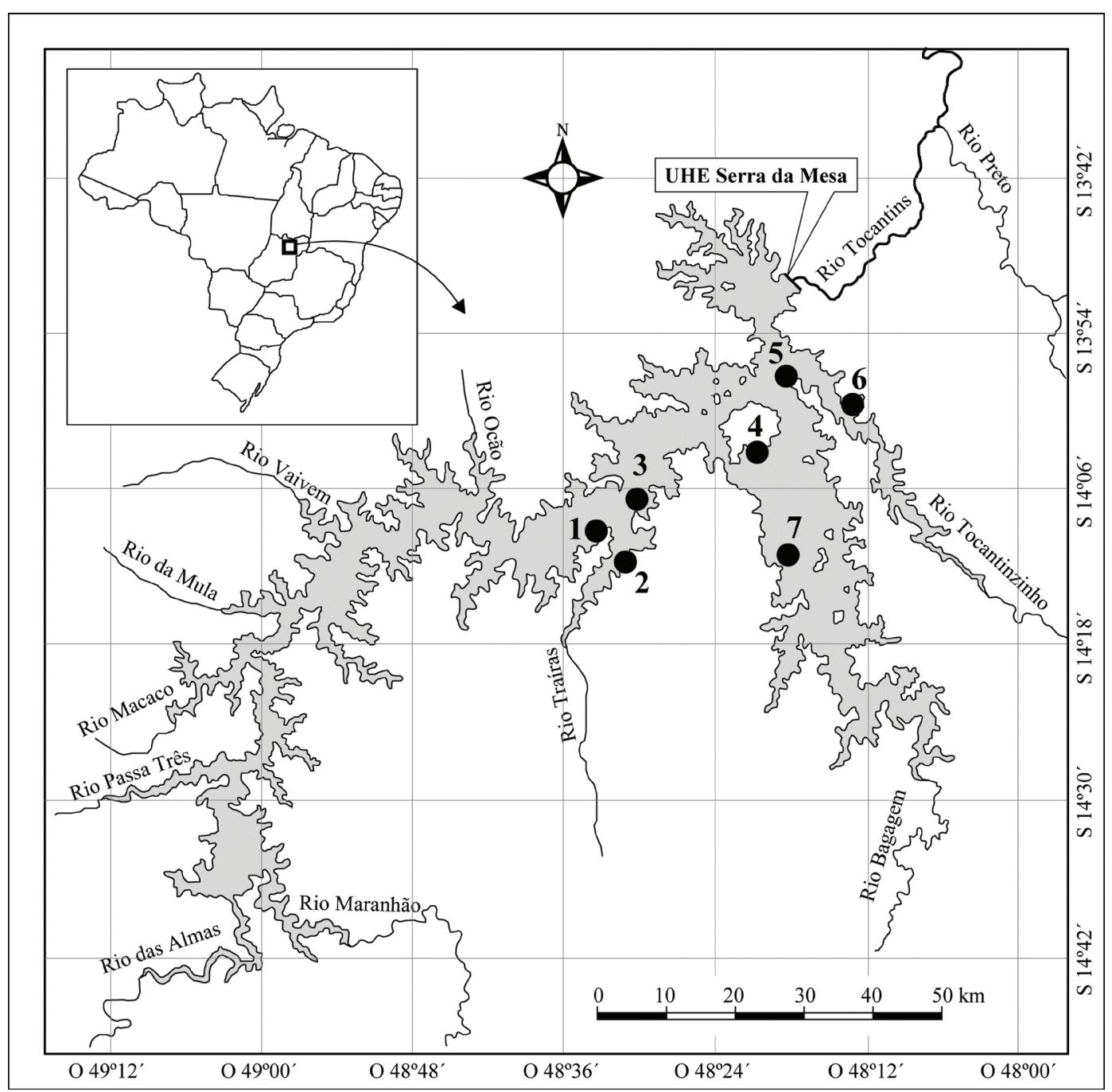

Figure 1. Location of the Serra da Mesa Reservoir in Brazil. The numbers 1-7 represent the sampling points.

aquatic insect abundance, with each point as a sampling unit and the season (dry or rainy) as the group variable. NMDS is a method of ordination, and the Bray-Curtis dissimilarity was used as a measure of distance (Legendre and Legendre, 1998). We used a maximum number of iterations 250 to obtain the minimum stress. This method does not assume linearity or normality of the data.

To evaluate the influence of the dry and rainy seasons on the aquatic insect community, paired tests comparing the beta diversity, richness, and abundance at each point in the dry and rainy seasons were performed. Therefore, the null hypothesis that there was no difference between the dry and rainy periods for these attributes was tested. The beta diversity was estimated using the dissimilarity measure estimated by the quantitative index of Sorensen (Chao et al., 2005). This index uses the relative abundance to measure the degree of distinction in taxonomic composition at each site, and the mean of this distinction is the measure of beta diversity. To assess whether the variations in the water level would cause changes in the community structure, we calculated the Pearson correlation index between these attributes and the reservoir level. This analysis used the logarithm of the abundance to reduce the weight of the dominant groups. The reservoir levels were obtained using data provided by FURNAS (manager of the Serra da Mesa Reservoir).

Because it was not possible to identify some taxa more specifically, the family level was the taxonomic resolution used in all analyses, thereby allowing the maintenance of a pattern between all the groups. Furthermore, the family level responds in a similar manner as more specific levels, such as genus and species (Marshall et al., 2006). All analyses were performed using the $\mathrm{R}$ platform, version 2.15.3, of the R Development Core Team (2012), with the aid of the MASS (Venables and Ripley, 2002) and Vegan (Oksanen, 2005) packages. The level of significance adopted was $\alpha<0.05$. 


\section{Results}

We collected 35,028 larval forms of aquatic insects $(9,513$ in dry period and 25,515 in the rainy season) belonging to seven orders (Table 1). Among the 33 families collected, only 12 occurred in the dry season, while all occurred in the rainy season. The order Diptera was the most abundant, with approximately $80 \%$ of the total sampling; of these, the Chironomidae family was the most representative, with 27,376 specimens collected. The second most abundant order was Ephemeroptera, with 2,317 specimens; Trichoptera was the third, with 1,758 specimens.

The richness and abundance were higher in the rainy season than the dry season (Table 1). Nonetheless, the Chironomidae family was responsible for most of the specimens in both periods, contributing over $76 \%$ of the relative abundance in the rainy season and $81 \%$ in the dry season (Figure 2). However, the orders Ephemeroptera and Trichoptera were higher in the dry season.

The composition of the aquatic insect community differed between the sampling periods (rainy and dry), showing a clear correlation between the points collected in the same season (Figure 3 ). The ordination reached a final stress value of $13,335(\mathrm{p}<0.05)$. The values of beta diversity, richness, and abundance were higher in the rainy season (Figure 4).

The reservoir level ranged from 52.75 meters in the dry season to 69.92 meters in the rainy season, and these variations influenced the richness $(r=0.75, p<0.05)$ and abundance $(\mathrm{r}=0.57, \mathrm{p}<0.05)$ of aquatic insects but not the beta diversity $(\mathrm{r}=-0.21, \mathrm{p}>0.05)$.

Table 1. Taxonomic composition and abundance of the families of aquatic insects collected in the Serra da Mesa Reservoir, Goiás.

\begin{tabular}{|c|c|c|c|}
\hline \multirow{2}{*}{ Order } & \multirow{2}{*}{ Family } & \multicolumn{2}{|c|}{ Season } \\
\hline & & Dry & Rainy \\
\hline \multirow[t]{5}{*}{ Diptera } & Chironomidae & 7755 & 19621 \\
\hline & Ceratopogonidae & 39 & 605 \\
\hline & Chaoboridae & 0 & 414 \\
\hline & Tabanidae & 0 & 5 \\
\hline & Empididae & 0 & 1 \\
\hline \multirow[t]{8}{*}{ Hemiptera } & Notonectidae & 7 & 153 \\
\hline & Corixidae & 0 & 1055 \\
\hline & Belastomatidae & 0 & 52 \\
\hline & Vellidae & 0 & 11 \\
\hline & Nepidae & 0 & 7 \\
\hline & Naucoridae & 66 & 29 \\
\hline & Noteridae & 0 & 15 \\
\hline & Hydrometridae & 0 & 1 \\
\hline \multirow[t]{9}{*}{ Coleoptera } & Girynidae & 0 & 124 \\
\hline & Elmidae & 0 & 12 \\
\hline & Dytiscidae & 0 & 3 \\
\hline & Curcullionidae & 0 & 2 \\
\hline & Hidrophilidae & 0 & 3 \\
\hline & Ptylodactilidae & 0 & 1 \\
\hline & Torrindicolidae & 0 & 1 \\
\hline & Staphylinidae & 0 & 1 \\
\hline & Scirtidae & 0 & 3 \\
\hline \multirow[t]{4}{*}{ Ephemeroptera } & Caenidae & 183 & 869 \\
\hline & Baetidae & 532 & 470 \\
\hline & Leptohyphidae & 4 & 255 \\
\hline & Leptophlebiidae & 3 & 1 \\
\hline \multirow[t]{3}{*}{ Odonata } & Libellulidae & 74 & 447 \\
\hline & Coenagrionidae & 44 & 400 \\
\hline & Gomphidae & 0 & 1 \\
\hline \multirow[t]{3}{*}{ Trichoptera } & Polycentropodidae & 801 & 880 \\
\hline & Hydroptilidae & 0 & 67 \\
\hline & Leptoceridae & 5 & 5 \\
\hline \multirow[t]{2}{*}{ Lepidoptera } & Pirallidae & 0 & 1 \\
\hline & Total & 9513 & 25515 \\
\hline
\end{tabular}




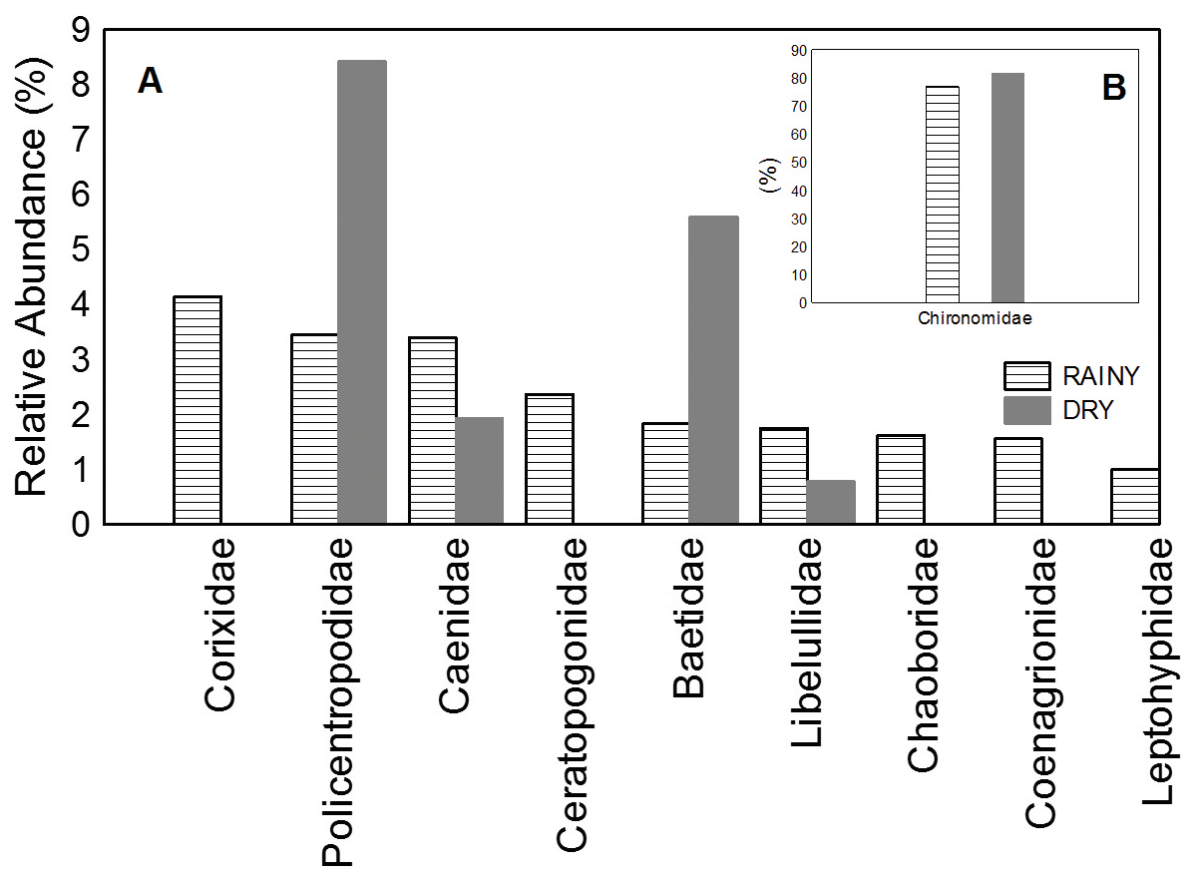

Figure 2. Relative abundance in the dry and rainy seasons for the aquatic insect families sampled in the Serra da Mesa Reservoir. (A) Families contributing $\sim 90 \%$ of abundance without Chironomidae and (B) relative abundance of the Chironomidae family, which is separated due the high value in both seasons.

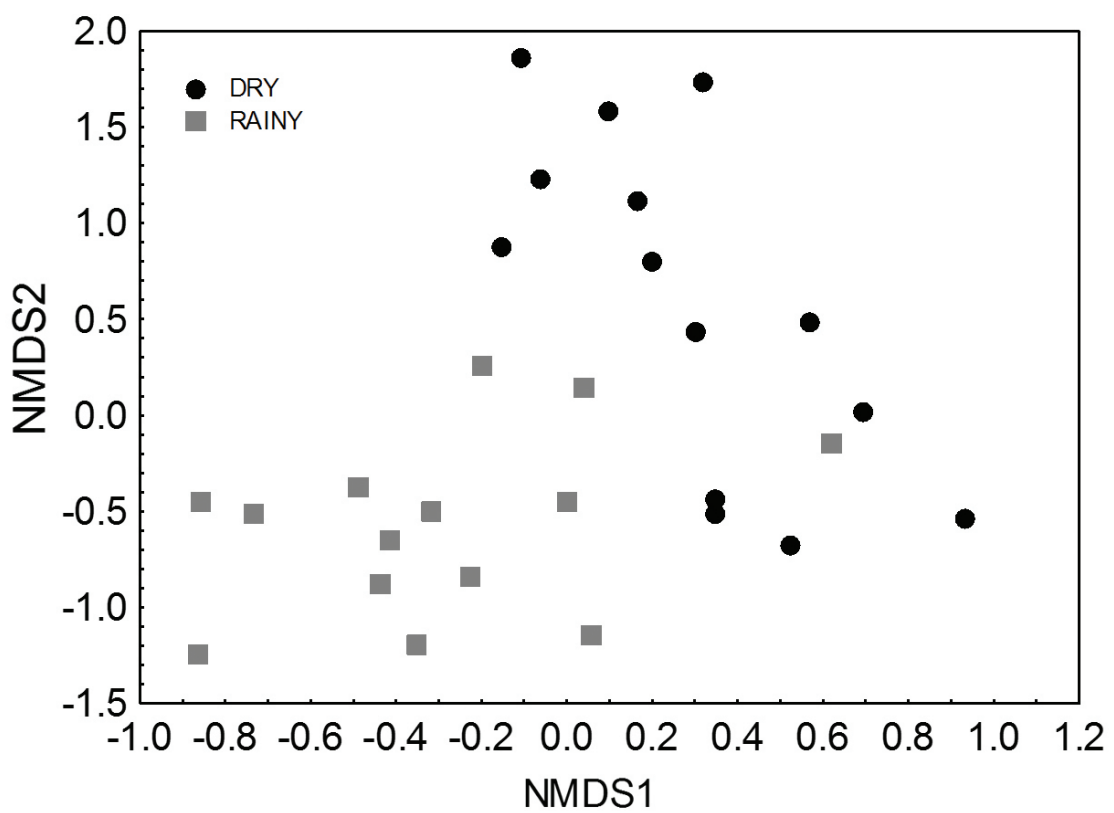

Figure 3. Analysis of Non-metric Multidimensional Scaling (NMDS) of the assemblage of aquatic insects in the Serra da Mesa Reservoir, Brazil.

\section{Discussion}

Testing our initial hypothesis, we found that the richness, diversity, and abundance of insects were higher in the rainy season, most likely due to the increase in habitat heterogeneity and input of allochthonous material during this period. Regardless, it is important to note that the majority of the individuals collected belonged to the Chironomidae family. This result can be attributed to their ability to colonize, as most of the species of this family can tolerate low water-quality conditions, such as 


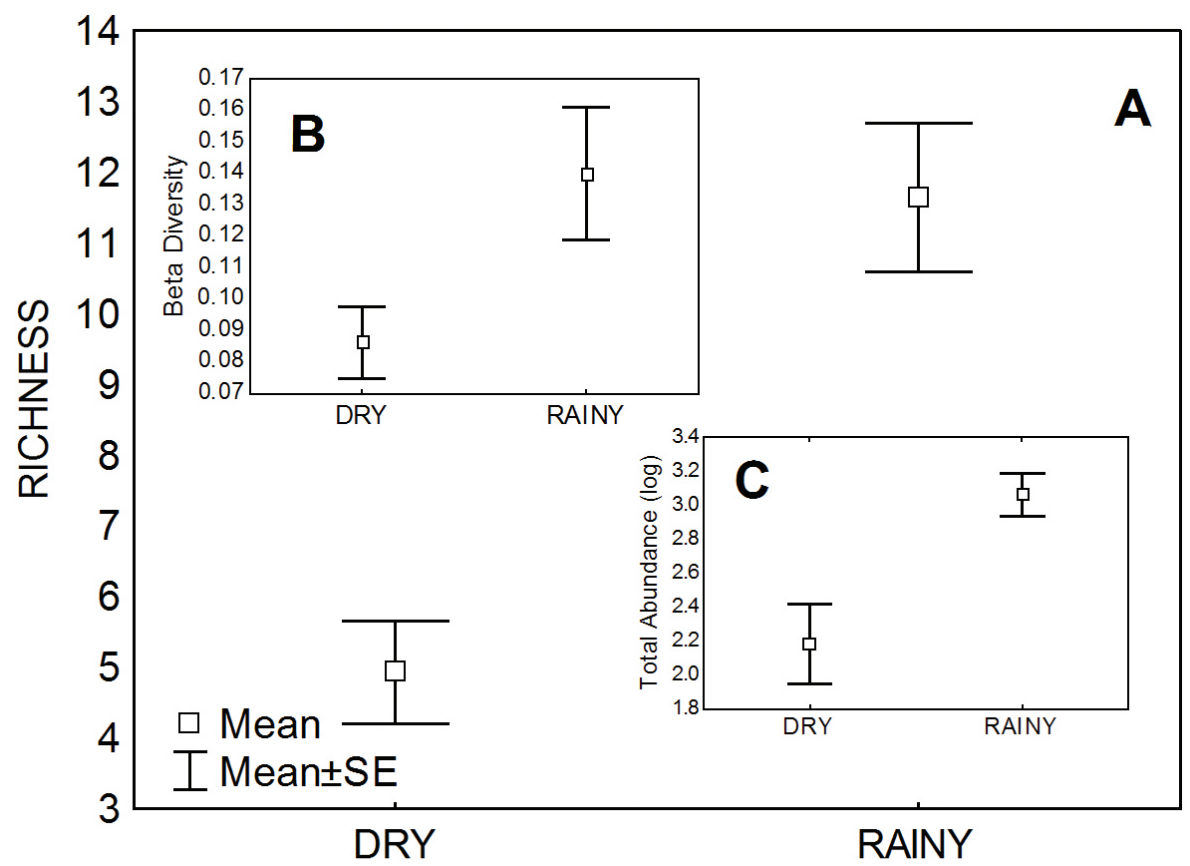

Figure 4. Paired t test for heterogeneous variances applied to the variation of the richness (A), beta diversity (B), and abundance $(\mathrm{C})$, aquatic insects in the two seasons sampled. All values were significant $(\mathrm{p}<0.05)$. Means are related to average values per point in each season (dry and rainy).

polluted environments (Simião-Ferreira et al., 2009), and low oxygen concentrations (Lee et al., 2006). Moreover, these insects live in high densities (Piedras et al., 2006), increasing their numerical abundance.

In addition to Chironomidae, the families Baetidae and Caenidae (Ephemeroptera) and Polycentropodidae (Trichoptera) were very abundant at several sampling points. However, these families are characteristic for belonging to orders that are considered good indicators of environmental quality (Barbola et al., 2011). Therefore, the findings suggest that the dominance of Chironomidae is not directly associated with poor conditions of the environment under study but most likely to the availability of organic matter, which serves as both food and refuge for the species of Chironomidae.

The seasonal rainfall of central Brazil is one of the main environmental factors controlling the aquatic biota (Bittencourt-Oliveira et al., 2012; Santos-Wisniewski and Rocha, 2007) because the temperature variations do not have sufficient amplitude to alter the patterns of the communities. Indeed, the structure of the aquatic insect communities is dependent, among other factors, on the physical-chemical conditions of the water, substrate availability, and biological interactions (Silveira et al., 2006; Vannote et al., 1980). Although we did not obtain information on the physic-chemical parameters of the water, we noted the influence of the increasing water level on the community because the highest values of richness and abundance were observed in the two samples collected in the rainy season.
Normally, the pattern of the influence of seasonality on the richness and abundance of benthic macroinvertebrates in lotic systems is based on the dry season providing better conditions for most families (Bispo and Oliveira, 1998). In contrast, the richness and abundance in the Serra da Mesa Reservoir increased in the rainy season, time at which the level water increased approximately 17 meters. This increase flooded a large degree of the vegetation, providing better conditions to the specialists families (Thornton et al., 1990; Esteves, 1998) and a greater availability of food due to the input of the allochthonous material that is critical to the functioning and balance of aquatic communities (Rezende and Mazzoni, 2005). Families like Corixidae, Hidroptilidae, Caenidae and Leptohyphidae, are directly dependent on the amount of vegetal material in the environment, and all increased their abundances in the rainy season.

Therefore, the pattern of greater abundance during the rainy season is the opposite to that found in streams because richness in the latter environments is reduced due to larval drift caused by rainfall (Baptista et al., 2001; Bispo et al., 2001, 2006; Thomazi et al., 2008).

Is important to note that the variations in the reservoir level are controlled according to the production of energy, causing daily changes in the level and potentially influencing the community structure (Agostinho et al., 2000). Additionally, Hunt and Jones (1972) highlight that a rapid decrease in the water level can exclude individuals from the water, which then die when exposed to the sun. Furthermore, Prus et al. (1999) concluded that a range of variation in water level of up to two meters does not alter 
the structure of the community, whereas 10 meters can be sufficient to cause species loss. At our study site, the level varied approximately 17 meters during the period examined, which caused the almost complete restructuring of the community, with the exception that Chironomidae continued to be the most abundant.

\section{Acknowledgements}

We are very thankful to the Brazilian Institute of Environment (IBAMA) for their financial support and the University State of Goiás for the support received from the "Programa de Bolsa de Incentivo à Pesquisa" (PROBIP).

\section{References}

AGOSTINHO, AA., OKADA, E.K. and GREGORIS, J., 1999. A pesca no reservatório de Itaipu: aspectos socioeconômicos e impactos do represamento. In HENRY, R. (Ed.). Ecologia de reservatórios: estrutura, função e aspectos sociais. Botucatu: FUNDIBIO/FAPESP. p. 281-319.

AGOSTINHO, AA., THOMAZ, SM., MINTE-VERA, CV. and WINEMILLER, KO., 2000. Biodiversity in the high Paraná river floodplain. In GOPAL, B., JUNK, W.J. and DAVIS, JA. (Eds.). Biodiversity in Wetlands: assessment, function and conservation. Leiden: Backhuys Publishes. 353 p. vol. 1.

AGOSTINHO, AA., PELICICE, FM. and GOMES, LC., 2008. Dams and the fish fauna of the Neotropical region: impacts and management related to diversity and fisheries. Revista Brasileira de Biologia = Brazilian Journal of Biology, vol. 68, no. 4, suplemento 4, p. 1119-1132. http://dx.doi.org/10.1590/S151969842008000500019. PMid:19197482

ALBRECHT, MP., CARAMASCHI, EP. and HORN, MH., 2009. Population responses of two omnivorous fish species impoundment of a Brazilian tropical river. Hydrobiologia, vol. 627, no. 1, p. 181-193. http://dx.doi.org/10.1007/s10750-009-9727-7.

ALMEIDA, VLS., LARRAZÁBAL, MEL., MOURA, AN. and MELO JÚNIOR, M., 2006. Rotífera das zonas limnética e litorânea do reservatório de Tapacurá, Pernambuco, Brasil. Iheringia Série Zoologia, vol. 96, no. 4, p. 445-451.

ANDRADE, SM., 2002. O patrimômio histórico arqueológico Serra da Mesa: a construção de uma nova paisagem. São Paulo: Universidade de São Paulo. 266 p. Tese.

BARLETTA, M., JAUREGUIZAR, AJ., BAIGUN, C., FONTOURA, NF., AGOSTINHO, AA., ALMEIDA-VAL, VMF., VAL, AL., TORRES, RA., JIMENES-SEGURA, LF., GIARRIZZO, T., FABRÉ, NN., BATISTA, VS., LASSO, C., TAPHORN, DC., COSTA, MF., CHAVES, PT., VIEIRA, JP. and CORREA, MF., 2010. Fish and aquatic habitat conservation in South America: a continental overview with emphasis on neotropical systems. Journal of Fish Biology, vol. 76, no. 9, p. 2118-2176. http:// dx.doi.org/10.1111/j.1095-8649.2010.02684.x. PMid:20557657

BAPTISTA, DF., BUSS, DF., DORVILLÉ, LF. and NESSIMIAN, JL., 2001. Diversity and habitat preference of aquatic insects along the longitudinal gradient of the Macaé River basin, Rio de Janeiro, Brazil. Revista Brasileira de Biologia = Brazilian Journal of Biology, vol. 61, no. 2, p. 249-258. PMid:11514892.

BARBOLA, IF., MORAES, FPG., ANAZAWA, TM., NASCIMENTO, EA., SEPKA, ER., POLEGATTO, CM., MILLÉO, J. and SCHÜHLI,
GS., 2011. Avaliação da comunidade de macroinvertebrados aquáticos como ferramenta para o monitoramento de um reservatório na bacia do rio Pitangui, Paraná, Brasil. Iheringia Série Zoologia, vol. 101, no. 1-2, p. 15-23.

BISPO, PC. and OLIVEIRA, LG., 1998. Distribuição espacial de insetos aquáticos (Ephemeroptera, Plecoptera e Trichoptera) em córregos de Cerrado do Parque Ecológico de Goiânia, estado de Goiás. In NESSIMIAN, J.L. and CARVALHO, A.L. (Eds.). Ecologia de insetos aquáticos. Series Oecologia Brasiliensis, vol. V.

BISPO, PC., OLIVEIRA, LG., CRISCI, VL. and SILVA, MM., 2001. A pluviosidade como fator de alteração da entomofauna bentônica (Ephemeroptera, Plecoptera e Trichoptera) em córregos do Planalto Central do Brasil. Acta Limnologica Brasiliensia, vol. 13, no. 2, p. 1-9.

BISPO, PC., OLIVEIRA, LG., BINI, LM. and SOUSA, KG., 2006. Ephemeroptera, Plecoptera and Trichoptera assemblages from riffles in mountain streams of Central Brazil: environmental factors influencing the distribution and abundance of immatures. Revista Brasileira de Biologia = Brazilian Journal of Biology, vol. 66, no. 2B, p. 611-622. http://dx.doi.org/10.1590/S151969842006000400005. PMid:16906293

BITTENCOURT-OLIVEIRA, MC., DIAS, SN., MOURA, AN., CORDEIRO-ARAÚJO, MK. and DANTAS, EW., 2012. Seasonal dynamics of cyanobacteria in a eutrophic reservoir (Arcoverde) in a semi-arid region of Brazil. Revista Brasileira de Biologia = Brazilian Journal of Biology, vol. 72, no. 3, p. 533-544. http:// dx.doi.org/10.1590/S1519-69842012000300016. PMid:22990824

CHAO, A., CHAZDON, RL., COLWELL, RK. and SHEN, TJ., 2005. A new statistical approach for assessing similarity of species composition with incidence and abundance data. Ecology Letters, vol. 8, no. 2, p. 148-159. http://dx.doi.org/10.1111/j.14610248.2004.00707.x.

DAVANSO, R. and HENRY, R., 2006. A biodiversidade bentônica em lagoa marginal ao rio Paranapanema na zona de sua desembocadura, na represa de Jurumirim. Acta Scientiarum. Biological Sciences, vol. 28, no. 4, p. 347-357.

DE FILIPPO, R., GOMES, EL., LENZ-CÉZAR, J., SOARES, C B.P. and MENEZES, C.F.S., 1999. As alterações na qualidade da água durante o enchimento do reservatório da UHE Serra da Mesa - GO. In HENRY, R. (Ed.). Ecologia de reservatórios: estrutura, função e aspectos sociais. Botucatu: FUNDIBIO/ FAPESP. p. 321-346.

EDIA, EO., GEVREY, M., OUATTARA, A., BROSSE, S., GORÈNE, G. and LEK, S., 2010. Patterning and predicting aquatic insects richness in four West-African coastal Rivers using artificial neural networks. Knowledge and Management of Aquatic Ecosystems, vol. 398, no. 6, p. 1-15.

ESTEVES, FA., 1998. Fundamentos em limnologia. Rio de Janeiro: Interciência. 602 p.

FUREY, PC., NORDIN, RN. and MAZUMDER, A., 2006. Littoral benthic macroinvertebrates under contrasting drawdown in a reservoir and a natural lake. Journal of the North American Benthological Society, vol. 25, no. 1, p. 19-31. http://dx.doi. org/10.1899/0887-3593(2006)25[19:LBMUCD]2.0.CO;2.

HSU, C. and YANG, P., 2005. Examining the relationship between aquatic insect assemblages and water variables by ordination techniques. Formosan Entomology, vol. 25, p. 67-85.

HUNT, PC. and JONES, JW., 1972. The effect of water level fluctuations on a littoral fauna. Journal of Fish Biology, vol. 4, 
no. 3, p. 385-394. http://dx.doi.org/10.1111/j.1095-8649.1972. tb05687.x.

JORCIN, A. and NOGUEIRA, MG., 2008. Benthic macroinvertebrates in the Paranapanema reservoir cascade (southeast Brazil). Revista Brasileira de Biologia = Brazilian Journal of Biology, vol. 68, suplemento 4, p. 1013-1024. http://dx.doi.org/10.1590/S151969842008000500009. PMid:19197472

LEE, SM., LEE, SB., PARK, CH. and CHOI, J., 2006. Expression of heat shock protein and hemoglobin genes in Chironomus tentans (Diptera, chironomidae) larvae exposed to various environmental pollutants: a potential biomarker of freshwater monitoring. Chemosphere, vol. 65, no. 6, p. 1074-1081. http:// dx.doi.org/10.1016/j.chemosphere.2006.02.042. PMid:16624371

LEGENDRE, P. and LEGENDRE, L., 1998. Numerical ecology. Amsterdan: Elsevier. 853 p.

LUCCA, JV., PAMPLIN, PAZ., GESSNER, AF., TRIVINHOSTRIXINO, S., SPADANO-ALBUQUERQUE, AL. and ROCHA, O., 2010. Benthic macroinvertebrates of a tropical lake: Lake Caçó, MA, Brazil. Revista Brasileira de Biologia = Brazilian Journal of Biology, vol. 70, no. 3, p. 593-600. http://dx.doi.org/10.1590/ S1519-69842010000300016. PMid:20730346

MARSHALL, JC., STEWARD, AL. and HARCH, BD., 2006. Taxonomic resolution and quantification of freshwater macroinvertebrate from an Australian dryland river: the benefits and costs of using species abundance data. Hydrobiologia, vol. 572, no. 1, p. 171-194. http://dx.doi.org/10.1007/s10750-005-9007-0.

MERRITT, RW. and CUMMINS, KW., 1996. An introduction to the aquatic insects of North America. 2nd ed. Dubuque: Kendall/ Hunt. 721 p.

MUGNAI, R., NESSIMIAN, JL. and BAPTISTA, DF., 2010. Manual de identificação de macroinvertebrados aquáticos do estado do Rio de Janeiro. 1a ed. Rio de Janeiro: Technical Books. 173 p.

OKSANEN, J., 2005. Vegan: R functions for vegetation ecologists. Available from: $<$ http://cc.oulu.fi/_jarioksa/softhelp/vegan.html $>$.

R DEVELOPMENT CORE TEAM (2012). R: A language and environment for statistical computing. Vienna: R Foundation for Statistical Computing.

PALOMAKI, R., 1994. Response by macrozoobenthos biomass to water level regulation in some Finnish lake littoral zones. Hydrobiologia, vol. 286, no. 1, p. 17-26. http://dx.doi.org/10.1007/ BF00007277.

PAMPLIN, PA.Z. and ROCHA, O., 2007. Temporal and bathymetric distribution of benthic macroinvertebrates in the Ponte Nova Reservoir, Tietê River (São Paulo, Brazil). Acta Limnologica Brasiliensia, vol. 19, no. 4, p. 439-452.

PEIRÓ, DF. and ALVES, RG., 2006. Insetos aquáticos associados a macrófitas da região litoral da represa do ribeirão das Anhumas (município de Américo Brasiliense, São Paulo, Brasil). Biota Neotropica, vol. 6, no. 2, p. 1-9. http://dx.doi.org/10.1590/S167606032006000200017.
PIEDRAS, SRN., BAGER, A., MORAES, PRR., ISOLDI, LA., FERREIRA, OGL. and HEEMANN, C., 2006. Macroinvertebrados bentônicos como indicadores de qualidade de água na Barragem Santa Bárbara, Pelotas, RS, Brasil. Ciência Rural, vol. 36, no. 2, p. 494-500. http://dx.doi.org/10.1590/S0103-84782006000200020.

PRUS, T., PRUS, M. and BIJOK, P., 1999. Diversity of invertebrate fauna in littoral shallow Myczkowce dam reservoir in comparison with a deep Solina dam reservoir. Hydrobiologia, vol. 408-409, p. 203-210. http://dx.doi.org/10.1023/A:1017015515507.

REZENDE, CD. and MAZZONI, R., 2005. Seasonal variation in the input of allochthonous matter in an atlantic rain Forest stream, Ilha Grande-RJ. Acta Limnologica Brasiliensia, vol. 17, no. 2 , p. 167-175.

SANTOS-WISNIEWSKI, MJ. and ROCHA, O., 2007. Spatial distribution and secondary production of Copepoda in a tropical reservoir: Barra Bonita, SP, Brazil. Revista Brasileira de Biologia = Brazilian Journal of Biology, vol. 67, no. 2, p. 223-233. http:// dx.doi.org/10.1590/S1519-69842007000200007.

SILVA, FL., TALAMONI, JLB., BOCHINI, GL., RUIZ, SS. and MOREIRA, DC., 2009. Macroinvertebrados aquáticos do reservatório do rio Batalha para a captação das águas e abastecimento do município de Bauru, SP, Brasil. Revista Ambiente e Água, vol. 4, no. 2, p. 66-74. http://dx.doi.org/10.4136/ambi-agua.87.

SILVEIRA, MP., BUSS, DF., NESSIMIAN, JL. and BAPTISTA, DF., 2006. Spatial and temporal distribution of benthic macroinvertebrates in a Southeastern Brazilian river. Revista Brasileira de Biologia = Brazilian Journal of Biology, vol. 66, no. 2B, p. 623-632. http:// dx.doi.org/10.1590/S1519-69842006000400006. PMid:16906294

SIMIÃO-FERREIRA, J., DEMARCO JUNIOR, P, MAZÃO, GR. and CARVALHO, AR., 2009. Chironomidae assemblage structure in relation to organic enrichment of an aquatic environment. Neotropical Entomology, vol. 38, no. 4, p. 464-471. http://dx.doi. org/10.1590/S1519-566X2009000400004. PMid:19768263

THOMAZI, RR., KIIFER, WP., FERREIRA, PD. and SÁ, FS., 2008. A sucessão ecológica sazonal de macroinvertebrados bentônicos em diferentes tipos de atratores artificiais no rio Bubu, Cariacica, ES. Natureza On Line, vol. 6, no. 01, p. 1-8.

THORNTON, KW., KIMMEL, BL. and PAYNE, FE., 1990. Reservoir limnology: ecological perspectives. New York: A Wiley - Interscience Publication. 246 p.

VANNOTE, RL., MINSHALL, GW., CUMMINS, KW., SEDELL, JR. and CUSHING, CE., 1980. The River Continuum concept. Canadian Journal of Fisheries and Aquatic Sciences, vol. 37, no. 1, p. 130-137. http://dx.doi.org/10.1139/f80-017.

VENABLES, WN. and RIPLEY, BD., 2002. Modern applied statistics with $S$. New York: Springer-Verlag. $495 \mathrm{p}$.

WARD, JV. and STANFORD, JA., 1982. Thermal responses in the evolutionary ecology of aquatic insects. Annual Review of Entomology, vol. 27, no. 1, p. 97-117. http://dx.doi.org/10.1146/ annurev.en.27.010182.000525. 